\title{
PSYCHOLOGICAL IMPACT EVALUATION OF EARLY MARRIAGES.
}

\author{
Sadaf Ahmed ${ }^{1 \& 2}$, Saima Khan ${ }^{3}$, Malka Alia ${ }^{1}, \&$ Shamoon Noushad ${ }^{l}$ \\ Advance Educational Institute \& Research Centre-Karachi, Pakistan \\ Department of Physiology, UoK \\ Aga Khan University Hospital
}

Corresponding author: sadafivy@gmail.com

\begin{abstract}
Lower awareness of health knowledge, physical growth and development, women bearing children at early ages face higher risk of maternal health problems, disability and death, reinforces risking problems for their newborns as a result, early marriages are always being a very big issue in developing countries specially in primitive uncivilized districts of Asia including India, Pakistan and Bangladesh etc. Moreover it's a controversial fact that in civilized society, evidences of getting married in early ages are greatly increased because of our religious beliefs, norms and social impacts. Due to early marriages young girls don't have the ability to deal with responsibilities, early pregnancy and pregnancy-related mortality and morbidity, causing major physiological and psychological health issues in adolescent girls, resulting in losing relationship confidence and ability to maintain a healthy relationship. Purpose of the study was to evaluate the aspects of psychological disturbances occurring in married young girls along with depression rate and educational withdrawal, with comparison of unmarried young girls of the same age specifically there is a strong correlation between a woman's age at marriage and the education that she receives. Uniformly across the countries, early marriage is associated with lower educational attainment. Observational study was conducted through multi logistic structured questionnaire and girls in $\mathrm{b} / \mathrm{w}$ age of 13 to 35 were included. On the basis of above study it is concluded that early marriage, multiple responsibilities and early pregnancies are risk factors of depression and it is further evaluated that married girls are at higher level when compared with unmarried.
\end{abstract}

\section{KEYWORDS}

Pregnancy, early marriage, depression, psychological health issues

\section{INTRODUCTION}

Throughout the world number of girls are suffering as a result of early marriage, approximately $20-50 \%$ of girls are married by the age of 18 in developing countries (Somerset, 2000; UNICEF, 2012 \& Singh, 1996) and the ratio is higher in Sub Saharan Africa and South Asia (Singh, 1996 \& UNICEF, 2012) usually such girls are forced to marry with the man that are quit elder then them. After being married they have to look after their husbands the house and the children they give birth although they do not have the complete knowledge of being a wife and even don't have sufficient information about sex and childbirth (Somerset, 2000). Early marriage is the marriage done before or during adolescence (Somerset, 2000 \& UNICEF 2012). There are a number of reasons due to which girls are often forced to marry early that includes negative traditional or religious practices, social, economic and on sexual and reproductive health (Jain, 2007; UNICEF 2005 \& Barkat, 2003).The impacts of early marriages are very severing for girls. They are not allowed to get educated (ICDDR,B. 2007;Menshb, 1998). Alan Guttmacher Institute report states that early marriage is "universally associated with low levels of schooling(Glassier, 1998).According to UNICEF, about $60 \%$ to $70 \%$ girls are forced to married in early ages in several African and Asian countries (Somerset, 2000). Even their basic human rights are not provided to them. Because of this several psychological and physiological problems occur and usually lead to divorce or suicide (Gage, 2013). For girls who don't have old enough bodies for safe sexual intercourse, unavoidable sexual relations with their husbands can be traumatic (Ram, 2005 \& Puri, 2003). 'Sex in such type of relationships, that involves young girls, is usually not built upon consent but unfortunately is essentially forced upon the girls'. The result of that is sexual, physical and also psychological harms and suffering, which is commonly defined as gender-related violence (CHANGE, 1999 \& Ram, 2005). Studies showed that early marriage and early childbirth leads to higher rates of adolescent fertility and pregnancy related complications (Patel, 1999; Ra,j 2010 \& Aelmu, 1988). In several regions it is considered that the status of a girl is based upon the number of male offspring therefore frequent pregnancies are common(UNICEF, 1994). Unfortunately the rate of death of the married girls aged between 15-19years is twice as compare to the girls who marry after the age of 20 years. As their bodies are immature that's why their health is affected by giving birth to a child (UNICEF 1994; Smith, 2001). The most important component of mortality for girls aged 15-19 are Maternal deaths related to pregnancy and childbirth which accounts to 70,000 deaths per year worldwide (UNICEF, State of the World's Children, 2009). The chance of dying of the infant of girl married before 18 years is 60 percent then that of the infant of the mother older than 19 years (UNICEF, 2001; Smith, 2001; UNICEF, 2012). if the child even survives, there are more chances of the thing that it will have low birth weight or is weaker than the normal children is physiological and psychological manners (Mehra, 2004; Alemu, 1988). The seriousness of the problem can be observed in africa as $75 \%$ of the girls that are married under the age of 17 are mothers (Anti-Slavery, 1994). These mothers are particularly prone to anemia(J Community Med, 2009) because the bodies are not developed yet; 'she still has $4 \%$ of her height to gain and her pelvis will only be $82-88 \%$ of its fully grown width' (ASI, 1994). Because of this labor is often get slow and the baby becomes stuck, causing vesico and recto-vaginal fistulas, and incontinence. In many societies, incontinence results in desertion by the husband, family and friends, leaving the girl's mother to look after her and her children. Also because of the larger number of child bearing years of young girls, increasing the chances of miscarriages, infant death(UNICEF 2012;McKenna, 2001;Raj, 2009;UNFPA, 2005), cervical cancer (Nour, 2008), malnutrition, sterility and maternal death(UNICEF, 2012;UNFPA, 2005 \& Global, 2007). According to the latest records (Rawalpindi, Pakistan), in one year $50 \%$ of the cervical cancer patients are those who get married before the age of 20 years. The cancer found in these girls was at the age between 45-60 years and each of them have approximately 6 children (Medical News, 1999).Girls always think about love and good treatment, but they never realize the responsibility and the pressure that they have to face after the marriage (Berhane-Selassie, 1993).Often girls are eloped to get away from workload and the bad attitude from the family towards them.

Only quality and availability of health care not determine reproductive health but women`s position role in society and socio economic development also plays a part in it. Women's Health Federation states that women's health is often compromised not by 
lack of medical knowledge, but by infringements on women's human rights (Cook, 2011).

\section{METHODOLOGY}

Cross sectional and Observational study was conducted through questionnaire that was designed to record the demographic profile and determine the depression level in single as well as early married girls with questions regarding parental education and personal views about education, marriage and level of literacy of early married girls about reproductive health. Data was collected from 100 girls in between age of 13 to 35 . Married (before 20 years of age) girls were also included for comparison study while some extra questions were included for married girls to determine their depression levels, before and after marriage. SPSS (VERSION 7) is used for the computation of results.

Graphical data shows, $1.82 \%$ of girls having depression before marriage which increases up to $43.18 \%$ after marriage while $25 \%$ of collected data shows the rate of depression in both before and after marriage.

\section{RESULT}

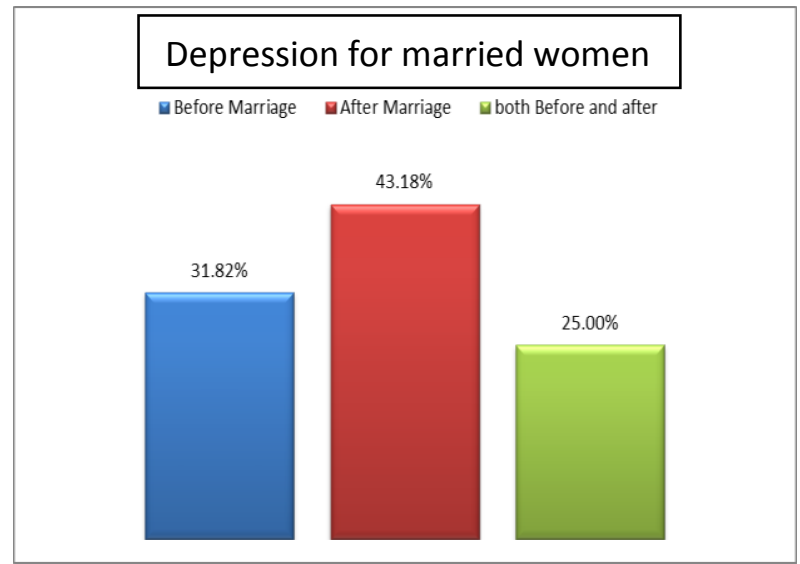

Fig: Depression rate in married women

Results shows that depression rate in single girls are in ratio of 15:10 i.e. $60 \%$ single girls are depressed. On the other hand $50 \%$ of married girls have depression which increases by $30 \%$ after marriage and is therefore $80 \%$. Additionally only $10 \%$ of single girls believes that marriage is a solution of frustration and remaining $90 \%$ are opposite of it.

\section{COMPARISON OF DEPRESSION RATE IN GIRLS BEFORE AND AFTER MARRIAGE}

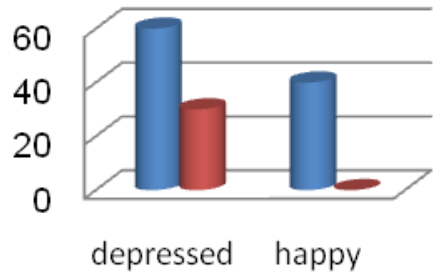

depression rate before marriage

depression rate after marriage

Fig: Increased rate of depression in women in comparison of before and after marriage.

\section{DISCUSSION}

Marriage is a step towards independency that introduces loads of responsibilities, decision making and serious commitments but early married girls fails to cope with it as marriage requires satisfactory level of maturity and considerable sense of responsibilities. Various factors are responsible for early marriages that include male dominancy, parents ignorance, lack of awareness, pressures from relatives and community, girls are regarded as burden so parents get rid of them by marrying them, parents believes that it offers protection to their daughters and to enhance family socio-economic status (Bayisenge, 2011). Women in developing states lack elementary health care and faces life-threatening healthiness problems comprehending maternal mortality, child marriage, human immunodeficiency virus (HIV)/AIDS, and cervical cancer are the few issues that wave developing lands (Nour, 2008). Early married girls are at higher risk of psychological disorders as these girls will be denied the right to freely express their views and the right to be defended against devastating traditional practices that in turn will increases risk of lifetime and recurrent psychiatric disorders. The overall lifetime and 12-month rates of psychiatric disorders were higher for women who married as children (before the age of 18 years), compared with women who married as adults. In addition, early married women are more likely to seek and access health services as compared to women in adulthood(Le, 2011).This type of physical emotional and social torture leads to greater psychological traumas such as immobility, loss of self confidence and even among girls that were receiving education early marriage impede their education resulting in severe depression and having complex from other girls having good educational background and career opportunities which they lost (Singh,1996). These girls marriages are generally arranged by parents, any other family member or local leaders. In addition early married girls may more likely experiences violence from their husband or their in-laws but that's not so surprising as adolescent girls are more likely to have older husband and greater control over making decisions by husbands and in-laws (Raj, 2010).Maternal mothers are more likely to experience pregnancy related complications, delivery concerns as well as maternal mortality, inturn increases risk for neonatal death, premature or low-weight infants and poor health outcomes. Also some young inexperienced married girls having spouse much elder and more educated than them, fails to have same thinking as their husbands have and cause of these unmatched thinking when they are not perfectly able or to fulfill all the requirements, or sometimes on very minor issues they are degraded and look down upon by their husbands may beaten (UNICEF, 2005) and not allowed to go to their parents. Or in some cases they repeatedly sent back to their parents after beaten which cause greater psychological shock treatments as the victims suffer from feeling of instability and loss of self respect. Moreover this leads to more severity when they sent back to their husbands by their parents by saying to secure their social values and respect. Also some sort of physiological changes may leads to depression such as obesity, poor health and child bearing (Alemu, 1988). In some societies demand of male offspring to maintain their position and status causes mental torture and stress related traumas. For instance it is also observed that these kind of uneducated and stressed mothers are fails to educate their children on basic level and are not even able to contribute their children for their studies, as a result they are getting neglected by their children and are not able to make a friendly environment for them. Policies by government or non-government aimed to educate family and community, raising awareness involving parents and empowering girls through education and employment can help stop early marriages (Rahman, 2005). Moreover education is not only effective in delaying marriages, pregnancies and childbearing but also school based knowledge of reproductive health issues can be effective in changing attitudes practices that leads to risky sexual behavior in marriage (Dakar, 1984). 


\section{CONCLUSION}

With marriage there will be increased stresses and pressures and early married girls are more prone to marriage problems as their individuality has been interrupted. There should be health awareness programs conducted for the girls as well as their parent to overcome the problems caused due to early marriages. Also educational awareness programs are needed to improve their quality of lives.

\section{REFERENCES}

- Alemu, Z. (1988).Early marriage-the silent carnage of our women. Newsletter (Inter-African Committee on Traditional Practices Affecting the Health of Women and Children), (5), 5.

- $\quad$ Banerjee, B., Pandey, G. K., Dutt, D., Sengupta, B., Mondal, M., \& Deb, S. (2009). Teenage pregnancy: a socially inflicted health hazard. Indian journal of community medicine: official publication of Indian Association of Preventive \& Social Medicine, 34(3), 227.

- $\quad$ Barkat, A., \&Majid, M. (2003). Adolescent reproductive health in Bangladesh: Status, policies, programs and issues. POLICY Project Report, USAID Asia/Near East Bureau.

- Bayisenge, J. (2011). Early marriage as a Barrier to Girl's Education: A Developmental Challenge in Africa. An open paper presented at National University of Rwanda.

- Berhane-Selassie, T. (1993). Early Marriage in Ethiopia. informe presentado al Comité Interafricano de Prácticas Tradicionales que Afectan la Salud de Mujeres y Niños, Addis Abeba.

- Cook, R. J. (Ed.). (2011) Human rights of women: National and international perspectives. University of Pennsylvania Press.

- Gage, A. J. (2013). Association of child marriage with suicidal thoughts and attempts among adolescent girls in Ethiopia. Journal of Adolescent Health.

- Glasier, A., Gülmezoglu, A. M., Schmid, G. P., Moreno, C. G., \& Van Look, P. F. (2006). Sexual and reproductive health: a matter of life and death. The Lancet, 368(9547), 1595-1607.

- Global, A. (2007). New insights on preventing child marriage.

- ICDDR,B.(2007) Consequences of early marriage on female schooling in rural Bangladesh, Health and Science Bulletin,5(4),13-18.

- Jain S and Kurz K (2007), New Insights on Preventing Child Marriage: A Global Analysis of Factors and Programs, Washington, DC: ICRW.

- $\quad$ Le Strat, Y., Dubertret, C., \& Le Foll, B. (2011). Child Marriage in the United States and Its Association with Mental Health in Women. Pediatrics, 128(3), 524-530.

- Medical News (1999) 'Early Marriages Causing Cancer among Women'. MN Monitoring Desk.

- Mehra, S., \& Agrawal, D. (2004).Adolescent health determinants for pregnancy and child health outcomes among the urban poor. Indian Pediatr, 41(2), 137-45.

- Mensch, B. S., Bruce, J., \& Greene, M. E. (1998). The uncharted passage: girls' adolescence in the developing world. New York: Population Council.

- Nour, N. M. (2008). An introduction to global women's health. Reviews in Obstetrics and Gynecology, 1(1), 33.

- omerset, C. (2000). Early marriage: whose right to choose. Unpublished work.

- Patel, V., \& Oomman, N. (1999). Mental health matters too: gynaecological symptoms and depression in South Asia. Reproductive Health Matters, 7(14), 30-38.

- Puri, M., Cleland, J., \& Matthews, Z. (2003, May). Extent of sexual coercion among young female migrant workers and their sexual health problems in Nepal.In annual meeting of the Population Association of America, Minneapolis, MN, USA.

- Rahman, M. M., \& Kabir, M. (2005). Do adolescents support early marriage in Bangladesh? Evidence from study. Journal of Nepal Medical Association, 44(159).

- Raj, A. (2010). When the mother is a child: the impact of child marriage on the health and human rights of girls. Archives of disease in childhood, 95(11), 931-935.
- Raj, A., Saggurti, N., Balaiah, D., \& Silverman, J. G. (2009) Prevalence of child marriage and its effect on fertility and fertility-control outcomes of young women in India: a crosssectional, observational study. The Lancet, 373(9678), 1883 1889.

- Ram, N. D. U. (2005). Associations Between Early Marriage and Young Women's Marital and Reproductive Health Outcomes: Evidence from India.

- Rights of the Child: 'Role of the Family in the Promotion of the Rights of the Child. 'General discussion day 10 October Retrieved from http:// www.unicef.org /lac/ Role_of_the_family.

- $\quad$ Singh, S., \& Samara, R. (1996). Early marriage among women in developing countries. International family planning perspectives, $148-175$

- $\quad$ Smith, G. C., \& Pell, J. P. (2001). Teenage pregnancy and risk of adverse perinatal outcomes associated with first and second births: population based retrospective cohort study. BMJ: British Medical Journal, 323(7311), 476

- UNFPA.(2005) Child marriage fact sheet. State of the world population

- Unicef. (2001). Early marriage: child spouses. Innocenti Digest, 7(2)

- Unicef. (2005). Early marriage: A harmful traditional practice. A Statistical Exploration. UNICEF, New York, 32.

- UNICEF.(2012) Child protection from violence, exploitation and abuse 